\title{
PROBLEMATIC IDEOLOGIES IN TEACHER EDUCATION
}

\author{
Monica Jacobs \\ Department of General Didactics \\ University of Durban-Westville \\ DURBAN
}

\begin{abstract}
Absiracl
A critical problem facing educationists is the problematic quality of many teacher training courses. The major source of the problem seems to be the irrational ideological foundations on which these courses are often based. The research theme revolves around a particular type of problematic ideology, viz. lecuring course teams in teacher training whose members refuse to adopt an integrated, mutually-compatible approach when teaching studens how to teach. Such course teans insist on transferring contradictory, subjcctive views of teaching to student teachers. It is estimated that a high percentage of students amnually qualifying as teachers in South Africa are, from a professional point of view, incompetent to teach. The argument is outlined in three parts: statement of problem, theoretical arguments being forwarded to justify problematic ideologies, and possible solutions. Bearing in mind the far-reaching implications of the situation, the solution could be to appoint a prescriptive controlling body/inspectorate whose members' main task would be to raise teacher training standards in South Africa. Experience in more developed countries suggests that such a controlling body would only function effectively if composed of representatives from other social sciences, schools, future employers (of pupils), educationists, and the govenument.
\end{abstract}

\section{INTRODUCIION}

In this article evidence emanating from recent investigations into ideologies prevalent in teacher education is examined. The main argument is that a low quality of teaching in schools is often due to problematic didactic ideologies being imbedded in many teacher training courses. In a large number of teacher training institutions throughout the world, and therefore also in some teacher institutions in South Africa, this is a disturbing reality. Not only does it lead to a groundswell of frustrated hopes, ambitions, and anxieties among children, parents, and teachers, but it also impedes the probability of South Africa becoming a more productive and prosperous country.

Space does not allow semantic analyses of the many key terms pertinent to this discussion, eg. teaching, Didactics, teacher education, scientific theory, practice, curriculum, method, etc. Suffice to note that the sense in which these and other terms 
are used here, is more or less the same as the sense in which they are used by prominent South African educationists like Landman (1985), Marais (1987), I.N.Steyn $(1987,1988)$, Van der Walt (1988), Grebe (1988), H.J. Steyn (1988), the Van der Stoeps (1988), and others.

The term ideology, as used in this paper, indicates a set of ethical ideas that form the basis of a theory or system. This meaning of ideology is a deviation from Snyman's (1987) usage of the term, viz. " ideologie is 'n diskoers wat 'n partikuliere belang bevorder op 'n manier wat nadelig is vir ander en hulle oor hierdie nadeligheid mislei". (1987:372). It grieves me to disagree on this point with a philosopher whom I otherwise admire, but it would appear that his definition of ideology could be anachronic. It seems to be a backsliding to the meaning of the word as used by Marx. Many modern writers use the term in a more positive sense, indicating neither a true nor a false system of thought - just a coherent set of ethical ideas that form the basis of a theory or system. Compare, for instance, Snyman's interpretation to that of Bloom (1987:219):

Idcology today, in popular specch, is, in the first place, gencrally understood to be a good and necessary thing .... In short, ideology became identical to values, and that is why it belongs on the honor roll of terms by which we live.

So deeply ingrained is this modern meaning of ideology, that both the Webster's and the Oxford dictionaries underscore Bloom's interpretation of the term.

If an ideology consists of a collection of coherent, non-intracontradictory ideas, it is here being seen as a justifiable ideology; if it consists of a collection of incoherent, intracontradictory ideas, it is referred to as a problematic ideology. The latter kind of ideology is problematic because its ideas do not form a proper set. As such, it fails to achieve its basic purpose, i.e. to provide a basis for a theory or system. There is thus a certain similarity between Snyman's definition of ideology and my definition of problematic ideology.

The particular type of ideologies relevant here are didactic ideologies, viz. a set of ethical ideas that form the basis for a teaching theory or teaching system. The argument is presented in three parts: a statement of the problem, theoretical grounds for problematic ideologies, and the quest for solutions.

\section{STATEMENT OF PROBLEM}

Most educational researchers, regardless of their theoretical persuasion, would agree that problematic ideologies is a major problem in teacher education today. This 
article, however, is not so much directed at them as at academics from other study fields (the reason for this will become clear later on). It therefore demands a starting point where the problem is explained as sharply and as specifically as possible, to make the dilemma clear to academics not directly involved in teacher education.

The problem is how the quality of teacher education in South Africa can be further improved to ensure that the next generation of South Africans will have a higher quality of life than the present generation.

It should be underscored that teacher education is one of the vital determinants a a country's quality of school teaching and, therefore, of a nation's quality of life. Teaching is aimed at providing students with appropriate knowledge, skills, and values to make them intellectually and morally as fit as possible to improve the world in which they live. Thus, when teaching in a particular classroom, school or country is ineffective it means that a large proportion of its pupils do not grow intellectually and morally as rapidly as they should - a situation which has a negative effect on the quality of life in the country as a whole. There are obviously many causes of ineffective teaching. Research has repeatedly indicated, however, that teacher quality is probably the most significant determinant of pupil achievement (as opposed to such factors as expenditure per pupil, class size, instructional materials, syllabi, etc.). Fuller (1987:258) found that in no less than 27 recent empirical studies about the influence of teacher quality on pupil achievement the results showed that high quality teachers cause high pupil achievements, while poor teachers cause poor achievements. This realisation, of course, is nothing new. Already in 1944 the American Council on Teacher Education (1944:2) said it all:

The quality of a nation depends on the quality of its citizens. The quality of its citizens depends - not cxclusively, but in a critical measure - upon the quality of their education. The quality of their education depends more than upon any factor, upon the quality of their teachers .... The quality of the teachers depends largely upon the quality of their own education .... It follows that

the purpose and effectiveness of teacher education must be mallers of profound social concern.

It is therefore a source of some amazement that so many governments in the world apparently fail to introduce measures that will ensure that teacher education in their countries is of a high standard. From various developed countries like West Germany, the United States and Canada, educationists keep expressing grave concern about the matter (Brezinka, 1987; Manning, 1987; McGregor, 1978; etc.). It is my contention that in South Africa, too, there is much room for the improvement of teacher education.

The succinct version of the problem, as stated above, obviously requires substantiation and elaboration. In the rest of this paper it is examined in greater detail. 


\subsection{Empirical evidence of problematic ideologies}

The didactic ideology on which the average teacher training course is based tends to be a sensitive issue. Consequently, evidence in the form of recognized research reports of empirical studies done about problematic ideologies in previous decades are scarce.

With the exception of the remarkable publication by Lortie (1978), reports about specific cases were almost unobtainable until the beginning of the 1980 's. Since then a fair number of researchers have taken the bull by the horns (eg. Little, 1981; Griffin et al., 1983; Koehler, 1984; Clark et al., 1985; Goodman, 1985). Some of the most recent investigations of this nature have been conducted by Howey \& Zimpher (1986), Manning (1987), Hoover et al. (1988), Richardson-Koehler (1988), Grossman \& Richert (1988), and Boulianne \& Weston (1988). In all these projects (mostly case studies of specific teacher training courses) the findings indicated that the courses were weak, due to a lack of agreement between lecturers about the ideological basis of their course.

It needs to be emphasized that in none of these cases were ineffective training programmes the result of disagreements among lecturers working at different institutions. If that were the case, one could explain the situation by saying that different institutions have always adhered to different schools of thought, and thus the problem would be a mere theoretical one. The dilemma is caused by the fact that in each of these cases a team of lecturers working at the same institution, teaching the same students, often in the same subjects, advocated contradictory approaches to teaching.

Yet most of these studies have been conducted outside South Africa. To get the problem, as it exists in South Africa, into closer focus, it is useful to examine the only similar South African case study that could be traced.

In this project (Du Plessis, 1985) a particular teacher training course was evaluated. The modus operandi included questionnaires, interviews, direct observations, and group discussions; more than 300 students, teacher educators, and headmasters participated in the investigation.

The major finding, in the end, was that the course was weak due to the problematic didactic ideology on which it was based. The majority of students complained bitterly and repeatedly about the fact that different lecturers used different criteria when lessons were being assessed (Du Plessis, 1985:284). As one student commented:

It is impossible for anybody to work if one boss says "Build the house" and another one says "Break it down". But this is exactly what lecturers do to us. What is the student learning in this situation? What does anybody achicve? (Du Plessis, 1985:288). 
The ideological differences between lecturers in this case study clearly did not merely affect the assessment of students; in the nature of ideologies, it seeped through each and every component of their curriculum. This is evident, for example, in the remark of another student:

When we returned from the block session and spoke to our ... tutor, he mentioned that it would go against the principles of the academic world to dictate to academics how they should criticise lessons. What kind of principles are thesc? What right have they got to dictate to us if they won't accept the rules themselves? (Du Plessis, 1985:288)

As can be seen in this extract, an unsound ideology in a teacher education section of a university, inevitably spills over to other academic fields, casting doubt on the academic principles and competencies of the university staff as a whole.

What this case study showed - similar to the other case studies mentioned earlier - was that the teachers who taught the student teachers how to teach, could not explain what "effective teaching" was. As individuals they might, of course, have been able to describe good teaching. But as a group they could not. Ample evidence was given of the tremendous amount of disagreements, contradictions, and confusion in the ideology on which the course was based. The lecturers adamantly refused to agree on a coherent ideology. In the final analysis

it secms as if the majority of the course-team are more concerned with passing on their own beliefs to students, than with the challenges posed by social and cultural changes. Instead of wrestling at length with the complex issues of teaching, in a spirit of co-operation, they merely stake out their Ierritories and ignore the rest of the didactic community (Du Plessis, 1985:338-9).

Boulianne \& Weston (1988:106), in their case study, state the problem in even stronger terms:

The teachers repeatedly mentioned their lack of preparation in the actual teaching process .... The respondents staled that the professors lacked the competence to teach ... the respondents statcd that professional appointments arc based on political considerations ...

It would seem as though a team of teacher educators who read such evaluations about themselves, would upgrade the ideological basis of their course. Not so. In none of the case studies mentioned did the writers report any improvements at the end of the projects. Instead, researchers who attend meetings aimed at reform, usually have little more to report than deadlock-situations where they "experienced a sense of disappointment and frustration at the amount of disagreement expressed by participants" (Manning, 1987:20). One gets the impression that many lecturers concerned do not read the reports, a situation that would prove just how correct and serious the indictment against them is. Moreover, the ideological anomalies persist, with no end in view. 


\subsection{Incidence rate}

The core question, of course, is how widely-spread the problem is.

Due to the sensitivity of the issue, it would be a difficult task to establish the incidence rate. Even in regions where the matter has reportedly been investigated on a national scale (Bone, 1980 and 1987; Turney, 1977; McNergney, 1986) - England, Scotland, Australia, Sweden, Canada, most states in the U.S.A. - reports with actual figures are apparently treated as privileged information.

If the problem was, is, or will be researched in South Africa, it is unlikely that the incidence rate of institutions with low quality teacher training courses will be made known to the public (for obvious reasons). It is exactly on this kind of secrecy that perpetrators depend, and flourish.

Researchers are thus left with the dubious method of intelligent guesswork. In this vein one can argue that the situation in South Africa is at present perhaps no better than it was in British Columbia in 1978. In that year the McGregor Repon revealed that over ninety percent of teacher training institutions in British Columbia offered courses of a very low standard. The fact that McGregor recommended the appointment of a governmental controlling body which would lay down "policy concerning the preparation of teachers, monitor existing programmes, and approve all new programmes" - and other more stringent measures - suggests that problematic ideologies were at the root of the low standards (Bone, 1980:59).

Suppose a similar situation at present exists in South Africa. Then:

* If there are 120 teacher training institutions, with an average of 228 final-year students in each (Du Plessis, 1985:166), then there are approximately 27360 teachers per year who qualify.

* If ninety percent of them have taken professional courses of a low quality, it could mean that every year approximately 24500 incompetent teachers become licenced to teach.

- If each teacher teaches 50 children per year (a high school teacher actually teaches about 200 pupils per year), each year's crop of new, incompetent teachers teach about one-and-a-quarter million children per year.

* The accumulative effect of incompetent teachers is therefore incalculable. 


\section{THEORETICAL GROUNDS OF PROBLEMATIC IDEOLOGIES}

It was suggested above that the professional part of a teacher training course can be rendered almost useless if a team of teacher educators refuse to agree on an ideology. What happens when such an agreement is not reached is, for example, that one lecturer teaches that lesson preparation is good, another lecturer teaches that lesson preparation is bad. One teaches 'follow your own instincts regarding lesson preparation', another one teaches 'ask the school teachers whether you should prepare lessons', etc. etc. A student can wind up with twelve or more different prescriptions about lesson preparation. Suppose a student gets a hundred such prescriptions about how to teach from every lecturer, and each lecturer's set of ideas contradicts his colleagues' sets of ideas, the student ends up confused. The professional part of his course has limited value.

As might be expected from pedagogues who have vested interests in the propagation of problematic ideologies, lecturers involved forward a number of theories to justify their apparent irrational approach to teacher education. It is only fair to list and briefly discuss a few of these arguments here.

The first argument is based on Bruner's (1966) theory of instruction, viz. his emphasis on discovery learning. Using, for example, the dictum "(l)earning and problem-solving require the exploration of alternatives" (Bruner, 1966:198), it is argued that the more different ideologies and different theories of teaching a student comes into contact with, the more he will learn about teaching, and therefore the better he will teach. My objection to this is that the above argument is based on a half-baked knowledge of Bruner's theory. Bruner saw "exploration of alternatives" merely as a short, first phase in the learning process. He suggested it as a way to predispose or motivate learners before the actual learning of new material starts. The bulk of his theory revolves around the teacher's task to structure the new knowledge in such a way that the student is able to conceptualize and categorize it into a meaningful whole. Most learning psychologists will probably be disconcerted to hear that Bruner's theory is being distorted in this manner to justify the relapse into egocentric ideological discord prevalent in many teacher education institutions today. To student teachers the learning process can become meaningless. They may wait for real learning to start, but never get beyond the point of "exploring alternatives": " ... the gorge between theory and practice becomes deeper and wider, excavated by the very individuals who are pledged to fill it" (Wragg, 1974:vii)

The second argument sometimes used to give respectability to problematic ideologies is the value-relativism argument as propagated by theorists like Nietzsche, Freud, Weber, Fromm, Riesman, and others. From this perspective, many lecturers point out, 
'good' and 'bad' cannot be discovered by reason. The meanings of 'good' and 'bad' are entirely dependent on one's own subjective point of view. It is therefore exceedingly important, they argue, not to impose their own, or any other, didactic ideology on student teachers. On the contrary, the major functions of lecturers are to stand back and let students discover for themselves their own subjective meanings of what is 'good' and 'bad' teaching, all the while encouraging the students with slogans like 'be yourself!', 'become inner-directed!', 'discover the real you!' The only logical reply one can give to this argument is a question: If this is true, why do we need teacher education institutions? It must be the most expensive and most time-consuming visit a student will ever have to a circus on earth. It is also the shortest way (as Bloom rightly points out in his critique of relativism) to nihilism of the worst kind:

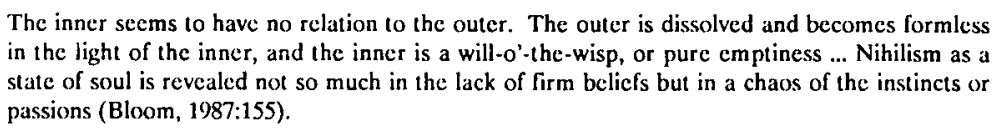

The inner seems to have no relation to the outer. The outer is dissolved and becomes formless in the light of the inner, and the inner is a will-o'-the-wisp, or pure emptiness ... Nihilism as a state of soul is revealed not so much in the lack of firm beliefs but in a chaos of the instincts or passions (Bloom, 1987:155).

There are other arguments. Examples: 'teachers are born, not made'; 'one can only learn to teach by teaching, not by learning theory'; 'the "bath by fire" approach is all that works'; 'textbooks will make up for poor teaching'; 'we must not be afraid to confuse students'; 'we must breed enquiring minds to bring about an alternative system'; 'our most important job is to demonstrate unconditional positive regard', etc. etc. To discuss them here will distract us from the main theme. Suffice to point out that all these notions have been disproved by educationists of calibre, like Dewey, Langeveld, Klafki, Van der Stoep, De Corte, Landman, Louw, Ausubel, Gage, Brophy, Nel, Van der Walt, and Grebe, to name but a few.

The tragedy of the above arguments is that they are propagated by academics. Students believe them. A student teacher ends his training with a set of chaotic and unworkable ideas about teaching. What little he knew at the start of his training has been destroyed by passionate pleas to apply the incorrect and extreme versions of the theories of Bruner and relativity in the classroom. His original "faulty" ideas have not been replaced by anything coherent. The course was useless, because it was based on a vacuum, instead of a research-based approach to teaching.

\section{THE QUEST FOR SOLUTIONS}

One cannot escape from the fact that the development of a justifiable ideology, acceptable to a large team of teacher educators working together, takes effort. The more lecturers involved, the greater the effort. But the effort is no different from the effort any academic team in any other study field constantly has to make to ensure that 
their courses are scientifically justifiable.

\subsection{Ideologies that are didactically justifiable}

An ideology accepted by a group of teacher educators, aimed at making a definite impact on students, should be sound enough for it to be a foundation on which a scientific theory can be built.

An ideology is a system of beliefs and norms. It is similar to a political party's policy, or a church's creed, or an individual's personal philosophy. As such, it may or may not be partly in written form. Certainly, when an ideology is accepted by a group of people, the tendency is to state the main principles in writing to minimize ambiguity; yet such a statement is never complete, because an ideology is too complex, too changeable, too rooted in a "steeds groeiende verwysingsraamwerk" (Marais, 1987:155) to be articulated in detail.

Once a course-team of teacher educators (i.e. a team who teaches the same students) agree on a didactic ideology (which should happen as soon as they start training teachers), scientific practice demands that they either acknowledge a well-known, scientific teaching theory, or formulate their own. Needless to say, the ideology and the theory must be congruent. This theory becomes the backbone of their courses. Without such a theory, the course can become an incoherent, bulky, irrelevant collection of verbalisms - as found in the case studies listed previously.

It is therefore clear that the major guideline for an ideology on which a meaningful teacher education course is based, is: if the ideology lends itself to the formulation of a didactic theory, it is justifiable; if not, the ideology is problematic.

The criteria which a didactic theory should fulfil, are well-documented. Apart from the obvious relevance of Kuhn's (1970) exposition of scientific principles, the requirements have recently been skillfully reformulated by, inter alia, Landman (1985), Marais (1987), I.N. Steyn (1987), and Grebe (1988). Landman (1985:124), for example, stresses the need for such a theory to meet the requirements of a discipline:

\footnotetext{
- 'n eic begrippestruktuur (basiese terminologie) wat verwys na inhoud,

- 'n bepaalde mensbeskouing, wat veral verwys na doclwitte,

- die dinamiese en ondersockende aard daarvan, wat verwys na metodologic,

- die kritiese ingesteldheid daarvan (veral selfkritick) wat kan verwys na kurrikulumevalucring.
} 
For a theory to be meaningful, the problem, paradigm and method choices must be congruent (Landman, 1985:125). The process demands at least three actions: reflection, verification, and description (Landman, 1985:124). In Grebe's more recent formulation, four essential features underpin a scientific educational theory: observational nesting, fertility, inter-theory support, and theoretical scope (1988:5-8). It seems unnecessary to elaborate further on these well-known, time-tested principles of good scientific practice. They are the same in all social sciences: utterly dependent on the acceptance by individuals of a coherent ideology decided upon by a group of scientists working together.

In science individualistic views are seen as being unreliable. If an academic's ideas about teaching are so insignificant that he cannot even find a small group of peers to agree with him, his ideas are unscientific and unacceptable. If a whole group consists of such individuals, and they cannot find common ground, their ideology is equally. unscientific and unacceptable. A justifiable ideology for a group of teacher educators therefore means, first and foremost: agreement on a coherent ideology. And a coherent ideology is one that leads to "systematic coverage of a single integrated approach" to teaching (Brophy, 1988:15).

In the section on Statement of problem evidence was presented to show that the ideologies on which many teacher training courses are based, are problematic. To solve the problem, three propositions are outlined and evaluated below.

\subsection{Proposition 1: An institutionally unifying ideology}

Using the principles of Landman and Grebe mentioned above, a team of teacher educators working together at the same institution, can agree on an institutionally unifying ideology. In the words of Liston \& Zeichner (1987:7):

Teacher educators who educate with moral deliberation as a goal must themselves confront a moral dilemma.

The moral dilemma they must confront is choosing between

* freedom that enables each lecturer to teach his/her own personal ideology, which results in a course that is unaccountable, or

* accepting the need for lengthy and continuous negotiations about ideologies and teaching theories, which results in a course that is accountable. 
A decision in favour of the latter is prerequisite for the establishment of a usefu teacher education course. Courses in teacher training that are not based on such an ideological agreement, are in my opinion unethical; they do not teach what they purport to teach. Thus, one way to improve teacher education in South Africa is for lecturing teams with problematic ideologies to voluntarily reform the ideological bases of their courses.

\subsection{Proposition 2: A departmental ideology}

Education departments who employ the teachers who qualify - and often pay for student teachers' studies - can prescribe an ideology as well as a teaching theory on which teacher educators at specific institutions have to base their courses. This implies that a particular education department would regularly inspect the quality of the courses at relevant institutions, and would only employ teachers who qualified at such 'approved' institutions.

\subsection{Proposition 3: A standardized ideology}

A state-appointed accreditation body can be created to negotiate an ideology on which all teacher education courses must be based. This implies that only teachers who qualified at approved institutions, which meet certain prescribed ideological and theoretical standards, will be employed by education departments. For such an accreditation body to have 'teeth', regular inspections of relevant institutions will have to be conducted.

\subsection{Evaluation of the three propositions}

In weighing up the value of the above propositions, two realities need consideration:

* The apparent inability of teacher educators to resolve these ideological problems among themselves.

* The seriousness of the situation.

It is due to these two realities that the present paper is mainly directed at academics from study fields other than Education.

One formidable obstacle in implementing the recommendation contained in Propo- 
sition 1, is that its success hinges on what Anderson (1987:36a) refers to as a "logic of confidence"; that is, an assumption that proper instruction is taking place without direct administrative supervision. Opting for an institutionally unifying ideology, without direct supervision, could lead to stagnation. In teacher training a "logic of confidence" often seems to result in a disregard of standards. To quote Greenfield (1983:17):

My complaint is that the values we bring to the effort to right the situation are precisely the ones that got us in trouble in the first place and are only likely to perpetuate our grief (Howey \& Zimpher, 1986:97).

It is because society, the government, other academics and parents, leave everything comfortably in the hands of teacher educators, that the quality of many courses deteriorates.

In the U.S.A., where problematic ideologies are perhaps more prevalent than in South Africa, teacher educators are also realising that a "logic of confidence" strategy simply does not work. Porter (1988:5) states:

... until recently, graduating from an accredited teacher training program satisfied the requirements for initial certification. This is the weakest approach to teacher assessment.

while Manning (1987:20) sadly admits:

... it secms very likely that educational reform in this country will remain where it has always been - with lay "experts".

Statements like these show the extent to which teacher educators in the U.S.A. - the fountainhead from whence problematic approaches to teacher training sprang - have been pulled up short by the revelation of Kozol (1985:4) that the functionally and marginally illiterate population of the U.S. now exceeds 60 million. At last they seem to face the fact that unsupervised teacher training is a failure.

The strategy set out in Proposition 1 is 'what got us into trouble in the first place'. A more promising approach would be purposeful action on the lines suggested either in Proposition 2 or Proposition 3. For this to succeed, it seems, teacher educators who are concerned about glaring defects in teacher education need the help of academics from other study fields across the university curriculum.

A major reason why the situation can only be rectified with the assistance of other social scientists, is that the problem is not a pedagogic-theoretical issue, but an interdisciplinary political issue. At many South African institutions (particularly many universities with liberal, left-wing policies) teacher educators in favour of justifiable 
ideologies seem to be outnumbered by those who support problematic ideologies (at the 1989 Congress of the Education Association of S.A., for example, there were only about 400 participants from a corpus of approximately 3000 teacher educators in S.A.) It is clear that many votes and voices from non-educationists would be needed to overrule the marked influence of teacher educators with laissez-faire attitudes towards ideologies - be it on micro or on macro levels of decision-making.

Without substantial assistance from influential academics, politicians, and other leaders of the South African community, teacher education at institutions where courses are weak cannot be improved. Proof for this can be found in the fact that hardly any improvements have thus far been achieved in relevant institutions. My impression is that the quality of their teacher training is rapidly declining. Despite the many voices of leading educationists who have in recent years pleaded for stronger scientific bases of Education courses - Nel (1984), Landman (1985), Marais (1987), I.N.Steyn (1987), Postma (1987), Grebe (1987, 1988), Wolfaardt et al. (1988), Van der Stoep \& Van der Stoep (1988), H.J. Steyn (1988), etc. - the status quo remains. Despite cohesive arguments of non-educationists in support of scientific methods in all social sciences (eg. Hartin, 1987; Moller, 1987; Snyman, 1987), many academics and politicians continue to turn a bland face and a deaf ear to calls for reform in teacher education. Despite education being the focal point of years of unrest in South Africa, the low quality of teacher education in a large number of institutions persists.

Evidence emanating from more developed countries suggests that the most effective way to improve teacher education on a national scale, is to increase external control over teacher training institutions. This evidence conflicts partly with the view of Van der Stoep \& Van der Stoep (1988:372):

\footnotetext{
... dat akkreditering op sy beste funksioncer as dit 'n vrywillige, self-regulerende aktiwiteit is, as dit liefs nie owerheidsgebonde is nie, en as dic gebruikers van die onderwys self die inisiatief uiloefen len atansien van die kontinue evaluering van gehalte by opleiding.
}

It would seem as if the latter view is based on the opinions of certain American educationists (reflecting, perhaps, some of the reasons for the 'sorry state' of American education in recent years - vide Kozol, 1985; Manning, 1987:21; Bloom, 1987, etc.). Even so, the Van der Stoeps' article makes it clear that their idea of 'gebruikers van die onderwys' is 'Departments of Education' which implies external control, and therefore their view partly co-incides with the suggestion in Proposition 2 above.

Space does not permit an overview of developments in countries where, in recent years, teacher education has shown improvement. However, for substantiation of the claim that external control is the only effective means to improve teacher training, a brief look at, for example, the recent successes achieved in Great Britain should prove 
the point. During the 1960's up to about 1975 teacher education in Britain was found to be unsatisfactory, mainly due to problematic ideologies (James' Report, 1972; Bone, 1980). It led to the involvement of the Council for National Academic Awards (C.N.A.A.) in teacher training (1973). Although this body, whose members are firmly committed to the value of peer group review, brought about some improvements, its successes were marginal (C.N.A.A., 1979). Only during the 1980's, when the Government took firm control of teacher education - both in colleges and in university departments of education - were courses effectively and dramatically upgraded with the establishment of a new controlling body: the Council for the Accreditation of Teacher Education (CATE). Their major method was regular inspections of teacher training institutions:

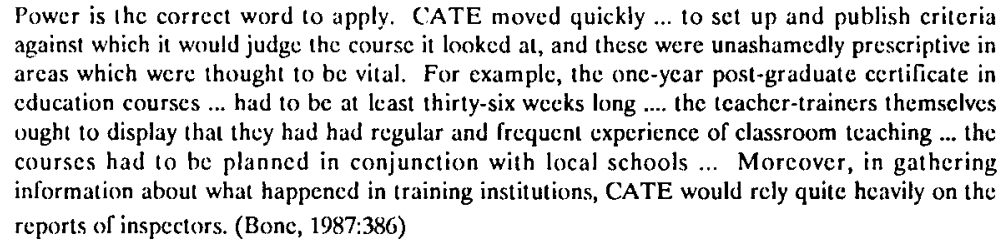

Power is the correct word to apply. CATE moved quickly ... to set up and publish criteria against which it would judge the course it looked at, and these were unashamedly prescriptive in areas which were thought to be vital. For example, the onc-year post-graduate certificate in education courses ... had to be at least thirty-six weeks long .... the tcacher-trainers themselves uught to display that they had had regular and frequent experience of classroom teaching ... the courses had to be planned in conjunction with local schools ... Moreover, in gathering information about what happened in training institutions, CATE would rely quite heavily on the reports of inspectors. (Bone, 1987:386)

The two most notable facts, in our present frame of reference, are that

* CATE is not controlled by teacher educators. It consists of working parties drawn from representatives of the schools, the future employers of pupils, teacher educators, and Government itself (Bone, 1987:385).

* CATE particularly inspects the ideological basis of each course - it should "form a coherent programme of study and be explicitly concerned with the classroom and professional needs of the teacher" (Bone, 1987:389).

The time seems to be overdue for South Africa to adopt similar measures. Already in 1985 Landman warned (1985:126):

Dic definiëring van dit wat basics is ... sal een van die mocilike take wees waarmee dic onderwys gekonfronteer sal word ... Dit beteken dat onderwyskundiges baie meer aandag moct gee aan regverdiging van waarom dit wat onderrig word ... behoort onderrig te word.

Nevertheless, little appears to have been done in certain quarters. In 1989 concerned educationists still have nothing more to say but to keep echo-ing Landman's sentiment, in a kind of broken-record fashion, eg.

Die aangelecntheid van akkreditering verdien op hierdie tydstip in ons onderwysontwikkeling die werklike noulettende aandag van die beleidmakers (Van der Stoep \& Van der Stoep, 


\section{8:375).}

In the meantime, every year large sums of money are being poured into teacher education courses of questionable quality. Much of this wealth, it seems, is paid to lecturers of the type aptly described by Bloom (1987:314): "A professional contemplative holding down a prestigious and well-paying job, and who also believes there is nothing to contemplate."

The most disturbing aspect, however, is not the material loss, nor the criticism from student teachers, nor the waste of time, nor even the disregard of scientific knowledge but the harm done to each successive generation of impressionable children left to the mercy of, what could very well be, an incompetent teaching force.

\section{CONCLUSION}

The purpose of this article was to shed light on serious ideological problems existing in some teacher training institutions. Partly because of clashing belief-systems, and partly because of the high degree of autonomy given to teacher education institutions, certain ideological anomalies appear to have become ingrained in a large percentage of teacher education courses. Many teacher educators insist on their 'right' to pass their personal, often dogmatic, beliefs about 'how to teach' to student teachers, instead of research-based facts. This frequently creates a problematic situation in which a team of lecturers attempt to teach a set of intra-contradictory ideas about teaching to the same corpus of student teachers. The minds of the students become a kind of battlefield on which lecturers with conflicting ideologies compete for superiority. More often than not, students emerge from such courses disillusioned, cynical, and unable to bridge the gulf between theory and practice.

To resolve the problem, it was suggested that academics from other study fields take a firm stand and strengthen the position of concerned educationists who are trying to establish high standards of teacher education in South Africa. These educationists believe that even in cases where the duration of such courses are only one or two years, curricula should be of an excellent standard. Unfortunately, teacher educators who support problematic ideologies of ten outnumber those who are in favour of justifiable ideologies. It would appear that the latter group needs strong support from social scientists, politicians, teachers, and the community at large for the creation of a controlling body to eradicate low standards in teacher education. 


\section{BIBLIOGRAPHY}

AMERICAN COUNCIL ON TEACHER EDUCATION. 1944. Teachers for our times. Washington : Commision on Teacher Education.

ANDERSON, L.W. 1987. The decline of teacher autonomy. Intemational Review of Education, 23:357376.

BLOOM, A. 1987. The closing of the American mind. New York : Simon \& Schuster

BONE, T. 1980. Current trends in initial training (In Hoyle, E. et at., Professional development of teachers. London : Kogan Page. p. 57-60.)

BONE, T. 1987. Changes in the training of teachers. Intemational Review of Education, 23:381-396.

BOULIANNE, R. \& WESTON, C. 1987. Discrepancy between preparation and practice in teacher education. Teaching \& Teacher Education, 3(2):99-107.

BREZINKA, W. 1987. The professional cthos of teachers. South African Joumal of Education 7(4):229234.

BROPHY, J. 1988. Educating tcachers about managing classrooms and students. Teaching \& Teacher Education, 4(1):1-18.

BRUNER, J. 1966. Learning about learning: A conference report. Cooperative Research Monograph, 15:197-204.

CLARK, D.C., SMITH, R.B., NEWBY, T.J., COOK, V.A. 1985. Perceived origins of tcaching behavior. Joumal of Teacher Education, 36(6):49-53

COUNCIL FOR NATIONAL ACADEMIC AWARDS. 1979. The Council, its place in British Higher Education. London : C.N.A.A.

DU PLESSIS, M. 1985. The development of a teaching practice curriculum: Durban. (Thesis. (D.Ed.) University of Durban-Westville.)

FULLER, B. 1987. What school factors raise achievement in the Third World? Review of Educational Research, 57(3):255-292.

GOODMAN, J. 1985. What students learn from carly ficld experiences: A casc study and critical analysis. Jounial of Teacher Education, 36(6):42-48.

GREBE, R. 1987. Clarity beforc commitment, Part I. Education: A scientific or ideological revolution? South African Joumal of Education, 7(4):240-245.

GREBE, R. 1988. Clarity beforc commitment, Part Il. Education: A scientific revolution? South African Joumal of Education, 8(1):1-9.

GREENFIELD, M. 1983. Newsweck column. New York Times: 17, Aug. 15.

GRIFFIN, G., BARNES, S., DEFINO, M., EDWARDS, S., HUKILL, H., \& O'NEAL, S. 1983. Clinical preservice teacher education: final report of a descriptive study. Austin : University of Texas.

GROSSMAN, P.L. \& RICHERT, A.E. 1988. Unacknowledged knowledge growth: A rc-cxamination of the effects of tcacher education. Teaching \& Teacher Education, 4(1):53-62.

HARTIN, PJ. 1987. An inquiry into the character of ethical statements and their verification and justification. Koers, 52(3):310-335.

HOOVER, N.L., O'SHEA, L.J. \& CARROLL, R.G. 1988. The supervisor-intern relationship and cffective interpersonal communication skills. Joumal of Teacher Education, 39(2):22-27.

HOWEY, R.H. \& ZIMPHER, N.L. 1986. New curriculum directions in education of teachers. Curricultum and Teaching, 1(1\&2):93-102.

JAMES REPORT. 1972. Department of Education and Science - Teacher Education and Training. London : H.M.S.O.

KOEHLER, V. 1984. University supervision of student teaching. Austin : University of Texas.

KOZOL, J. 1985. Illitcrate America. New York : Anchor Press/Doubleday.

KUHN, T.S. 1970. The structure of scientific revolutions. Chicago : University of Chicago Press.

LANDMAN, W.A. 1985. Enkele betekenisse van die begrip filosofic en die implikasies daarvan vir kurrikulumstudic. Suid-Afrikaanse Tydskrif vir Opvoedkunde, 8(3):122-127. 
LISTON, D.P. \& ZEICHNER, K.M. 1987. Reflective teacher education and moral deliberation. Jounial of Teacher Education, 38(6):2-8.

LITTLE, J. 1981. The power of organizational settings: School norms and staff development. Los Angeles : Amcrican Educational Research Association.

LORTIE, D. 1978. Schoolteacher. Chicago: University of Chicago.

MANNING, D.T. 1987. Historical lessons for teacher cducation. Joumal of Teacher Education, 38(6):2024.

MARAIS, DE LA REY. 1987. Kommunikasic in 'n pedagogicse tematisering. Koers, 52(2):149-165.

McGREGOR REPORT. 1978. The education and training of tcachers in British Columbia. Victoria : B.C.

MCNER(;NEY, R. \& AYLESWORTH, M. 1986. Evaluating prescrvice tcachers. Curriculum and Teaching, 1(1\&2):103-111.

MOLLER, P.H. 1987. Resensic-artikel: Die politicke rol van die sosiale wetenskappe en sosiaalwetenskaplikes in dic Suid-Afrikaanse samelewing. Koers, 52(3):336-354.

NEL, B.F. 1984. Education: A social science. South African Joumal of Education, 4(1):12-16.

P(ORTER, A.C. 1988. Understanding tcaching: A model for assessment. Joumal of Teacher Education, 39(4):2-7

POSTMA, W. 1987. Parent-teacher contact: A problematic matter. Koers, 52(3):252-273.

RICHARDSON-KOEHLER, V. 1988. Barriers to the effective supervision of student teaching: A field st udy. Joumal of Teacher Education, 39(2):28-34

SNYMAN, J.J. 1987. Idcologic en teologic. Kocrs, 52(4):362-383.

STEYN, H.J. 1988. Dic onderwysstelscl as vervlegt ingsstruktuur - enkele perspekticwe. Suid-Afrikaanse Tydskrif vir Opvoedkunde, 8(4):403-410

STEYN, I.N. 1987. Kurrikulumnavorsing vanuil Christclik-opvocdkundige perspektief. Kocrs, 52(2):135148

STEYN, I.N. 1988. What is tcaching? South African Joumal of Education, 8(2):159-163

TURNEY,C. 1977. Innovations in teacher education. Sydney : Sydney University Press.

VAN DER STOEP, F. \& VAN DER STOEP, I. 1988. Akkreditering in die onderwys: Opsics en moontlikhede. Suid-Afrikaanse Tydsknif vir Opvoedkunde, 8(4):370-376.

VAN DER WALT, J.L. 1988. Is Robin Barrow's method of philosophical analysis "irrationalistic"? Koors, 52(2):167-182.

VAN DER WALT, J.L. 1988. Robin Barrow's method of philosophical analysis in education. South African Joumal of Education, 8(3):255-260.

WOLVAART, J.S., SALEMINK, P., MYBURGH, C.P.H. \& ANDERSON, E.C. 1988. Die kwantifisering van behoeftes met dic oog op kurrikulering. Suld-Afrikaanse Tydskrif vir Opw'ocdkunde, 8(2):127-132.

WRACi(i, E.C. 1974. Teaching teaching. London : David \& Charles. 
